DOI: $10.1515 /$ pts-2016-0022

ENVIRONMENTAL MONITORING

\title{
IMPACT OF THE FORMER SALASPILS NUCLEAR REACTOR ON THE SURROUNDING TERRITORY
}

\author{
D. Riekstina ${ }^{1}$, J. Berzins ${ }^{1}$, T. Krasta ${ }^{1}$, G. Kizane ${ }^{2}$, J. Rudzitis ${ }^{2}$ \\ ${ }^{1}$ Institute of Solid State Physics, University of Latvia, \\ 8 Kengaraga Str., Riga, LV-1063, LATVIA \\ ${ }^{2}$ Institute of Chemical Physics, University of Latvia, \\ 19 Raina Blvd., Riga, LV-1586, LATVIA
}

\begin{abstract}
The paper presents results of the long-term environment radioactivity monitoring in the vicinity of the decommissioned Salaspils Nuclear Reactor. Data include Cs-137 contamination levels of soils, H-3 concentration in ground waters, as well as gross beta activity of sewage and rainwater drainage of SNR. Special attention is devoted to the radioactive pollution of water due to leakage from the special wastewater basin detected in December 2014.
\end{abstract}

Keywords: artificial radionuclides: Cs-137, H-3, beta-activity, environment radioactivity monitoring, nuclear reactor.

\section{INTRODUCTION}

Radiation hazard for population is a topic attracting nowadays growing attention. According to public opinion, nuclear reactors are regarded as the most dangerous potential sources of such hazards. The Salaspils Nuclear Reactor (SNR) near Riga had been in operation for a long period (1961-1998) which could have resulted in pollution of the closest surrounding territory with artificial radionuclides: products of activation or fission. The most important of these artificial radionuclides are Cs137, and $\mathrm{H}-3$.

The use of beryllium $(\mathrm{Be})$ cassette for neutron reflection in the reactor core resulted in the production of tritium in water of the reactor tank, and first contour. Nuclear reactions involved in the tritium production process (Eq.1) include fast neutron capture by ${ }^{9} \mathrm{Be}$ nuclei, and thermal neutron capture by ${ }^{6} \mathrm{Li}$ and ${ }^{3} \mathrm{He}$ nuclei, as well as beta-decay of ${ }^{6} \mathrm{He}$, and ${ }^{3} \mathrm{H}[1]$.

$$
\begin{gathered}
{ }^{9} \mathrm{Be}+\mathrm{n}(1-10 \mathrm{MeV}) \rightarrow{ }^{10} \mathrm{Be}^{*} \rightarrow{ }^{4} \mathrm{He}+{ }^{6} \mathrm{He}-0.64 \mathrm{MeV} ; \\
\downarrow 0.8 \mathrm{~s} \\
{ }^{6} \mathrm{Li}+\mathrm{n}(\text { th }) \rightarrow{ }^{6} \mathrm{H}+{ }^{4} \mathrm{He}+4.7 \mathrm{MeV}+\beta^{-} \\
\downarrow 12.3 \mathrm{yr}
\end{gathered}
$$




$$
\begin{gathered}
{ }^{3} \mathrm{He}+\beta^{-} \\
{ }^{3} \mathrm{He}+\mathrm{n}(\text { th }) \rightarrow{ }^{3} \mathrm{H}+\mathrm{p}^{-} .
\end{gathered}
$$

Tritium could have leaked into environment (in the form of vapour and contaminated water).

The regular Cs-137 monitoring of soils around the decommissioned SNR has been carried out since 1998. Activity monitoring of gamma- and beta-ray emitting radionuclides in the ground waters around SNR was started in 1990. Tritium monitoring of ground waters has been carried out since 1997. Some results have been published earlier in [2], [3].

The aim of present research is to provide an overview of the long-term study of presence and concentration of artificial radionuclides in soils and waters of the three kilometre radius area around SNR after its shutdown. Data include Cs-137 activity in soils, tritium and gross beta activity in ground waters and sewage. Accumulation and migration of artificial radionuclides in the soil and ground waters of SNR vicinity have been studied as well. The obtained results are compared with the background radioactivity level in the rest of Latvian territory [4], [5], as well as with national and EU regulation requirements [6], [7].

In December 2014, a high activity concentration $\left(\sim 5 \cdot 10^{3} \mathrm{~Bq} / 1\right)$ of tritium was discovered in the control wells near the special sewage water storage basins. The cause of this incident was water leakage due to basin's metal wall corrosion. Systematic radionuclide contamination control of water was carried out during all stages of deactivation and repair works. The present paper provides an overview of these measurements as well as takes stock of situation after the liquidation of this pollution source.

\section{EXPERIMENTAL PROCEDURE}

For the regular monitoring of Cs-137 activity in soils of the three kilometre zone around SNR, five fixed checkpoints were selected (3 points inside, and 2 points outside the SNR territory). Each sampling point had an area of $1 \mathrm{~m}^{2}$. Every year in August-September, 5 samples (sample size $-8 \mathrm{~cm} \times 8 \mathrm{~cm}$ ) were taken at each checkpoint from the upper soil layer $(0-5 \mathrm{~cm})$ and mixed. Then, samples were dried at $105{ }^{\circ} \mathrm{C}$ to attain constant weight, homogenized, filled into 11 Marinelli beakers and weighted. Radionuclide concentration measurements were performed using the gamma-ray spectrometry methods [8], [9] employing the high resolution HPGe gamma-ray spectrometers Ortec or Canberra with the Genie ${ }^{\mathrm{TM}} 2000$ software system [10]. Massic activity of Cs-137 in soil samples was determined from intensity of the $661.657 \mathrm{keV} \gamma$-line. The uncertainty of measurement results was within the range of $3-10 \%$, the minimal detectable activity (MDA) $-0.3 \mathrm{~Bq} / \mathrm{kg}$.

Gamma-ray spectrometers were calibrated for gamma-ray energy and efficiency measurements using certified mixed standard volume source traceable to NIST. Regular energy and efficiency stability checks of gamma-ray spectrometers were carried out using certified Co-60, Cs-137, and K-40 sources.

In order to monitor tritium concentration in the ground waters around SNR, 
control wells were made at distances ca. 5 to $200 \mathrm{~m}$ from the reactor tank and special sewage basins (see Fig. 1). Ten wells are located inside SNR territory, and twelve wells - outside the reactor fence. The control wells are numbered and grouped as A, $\mathrm{B}$, and $\mathrm{V}$ according to their depth as follows (see Fig. 2). The distance between A, $\mathrm{B}$, and $\mathrm{V}$ wells within groups $1-4$ is $1.2 \mathrm{~m}$; between wells $7 \mathrm{~A}$ and $7 \mathrm{~V}-0.75 \mathrm{~m}$; and between wells $8 \mathrm{~A}$ and $8 \mathrm{~V}-0.7 \mathrm{~m}$. The well $\mathrm{X} 1$ is $4 \mathrm{~m}$, and the well $\mathrm{X} 2-6 \mathrm{~m}$ deep.

The liquid scintillation counting method [11] was used for determination of tritium activity in ground waters. Collected samples of ground water were distilled and then mixed with a scintillation cocktail (OptiPhase "HiSafe" 3 ) in a polyethylene vial. The optimal mixing ratio was $8 \mathrm{ml}$ of distillate, and $12 \mathrm{ml}$ of scintillation cocktail. Measurements of tritium activities were performed with the liquid scintillation spectrometer (Packard TRI-CARB 2100 or Hidex 300 SL). Measurement time was up to 12 hours or until statistical uncertainty less than $2 \%$ was achieved. For this counting time, MDA was $4 \mathrm{~Bq} / 1$.



Fig. 1. Location of control wells in the territory of SNR.



Fig. 2. Depth distribution of control wells.

For determination of gross beta-activities [12], collected 11 samples of ground water and/or sewage were evaporated. Measurements were performed using the calibrated Tennelec-Solo device. 
Credibility of obtained results was ensured by the quality assurance and control according to the main requirements of the ISO/IEC 17025:2008 standard [13].

\section{RESULTS AND DISCUSSION}

\subsection{Monitoring of Soils in the SNR Territory}

Measurements of radioactivity in the soil samples of the three kilometre zone around SNR established only presence of Cs-137, as well as natural radionuclides: K-40, and decay products of Th-232 and U-238 chains [2]. It was found that concentration of Cs-137 differed significantly in the adjacent places. These variations could be explained by different sorption of Cs-137 in various soil types [14] and location of the checkpoint (grassland, plough land, coniferous or leafy forest, etc.). The massic activity of Cs-137 in the grassland and plough land was from 0.3 up to $26 \mathrm{~Bq} / \mathrm{kg}$. In forest, the massic activity of Cs-137 was from 38 to $227 \mathrm{~Bq} / \mathrm{kg}$. The maximal Cs137 massic activity in the SNR territory $-227 \mathrm{~Bq} / \mathrm{kg}$ - was found in the pine forest.

Let us compare these results with Cs-137 activity from the global fallout including Chernobyl. The average Cs-137 massic activity in the Latvian soil was determined at $140 \mathrm{~Bq} / \mathrm{kg}$ [5]. In the east part of Latvia, the maximal Cs-137 massic activity was determined at $319 \mathrm{~Bq} / \mathrm{kg}$, while in the west regions - between 150 and $950 \mathrm{~Bq} / \mathrm{kg}$ [4]. Therefore, the Cs-137 activity level in the SNR territory is below the contamination values established in Latvian soils [5], [15].

Figure 3 presents the minimal and maximal massic activity of Cs-137 in the vicinity of SNR for each year starting with 2003. The observed variations of Cs-137 massic activity depend on the soil material (clay, sand, or peat), and the location of sampling point (forest or grassland).

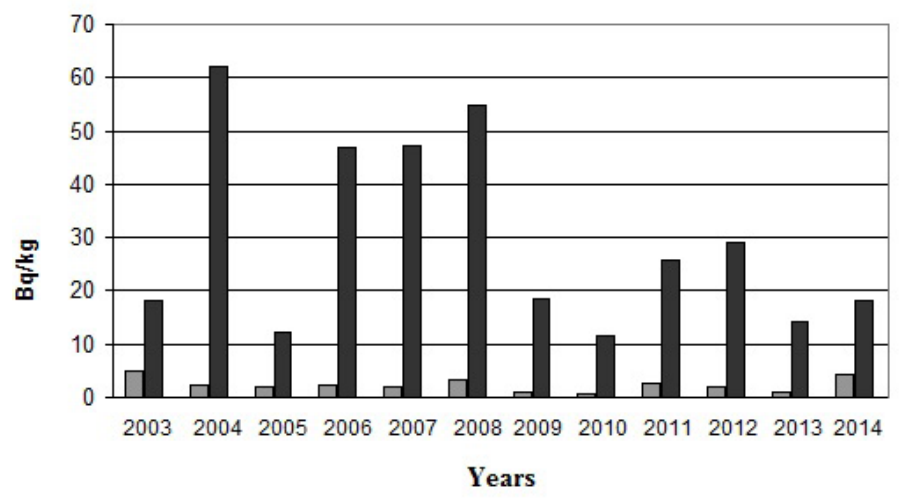

Fig. 3. Minimal and maximal annual massic activity of Cs-137 in the soils of SNR territory.

\subsection{Monitoring of Ground and Sewage Waters}

Figure 4 presents the results of tritium monitoring of ground waters in two control wells. The well 2B (see Figs. 1, and 2) is $4.3 \mathrm{~m}$ deep in the clay level and located on the ground water stream outside the reactor's fence. The well $10 \mathrm{~V}$ is 
$9.2 \mathrm{~m}$ deep in the limestone level close to the SNR wastewater basin No. 1. The distance between wells $2 \mathrm{~B}$ and $10 \mathrm{~V}$ is $\sim 50 \mathrm{~m}$. We compare data for ground water samples taken in October of each year. The established seasonal variations of tritium concentration related to the amount of precipitations are within $20 \%$ limits. The increased tritium concentration in the well $10 \mathrm{~V}$ in the period of 2003-2004 can be explained by the washing out of tritium from the gypsum caverns (within the SNR territory) due to meteorological conditions.



Fig. 4. Tritium concentration in wells $2 \mathrm{~B}$ and $10 \mathrm{~V}$.

Waters of the SNR territory were also monitored for the gross beta activity. In the ground waters, this activity varied in the range from 0.05 to $0.35 \mathrm{~Bq} / 1$. The allowed gross beta activity level for water is $1 \mathrm{~Bq} / 1$ [6]. The gross beta activity of water from the SNR sewage and rainwater drainage systems (Fig. 5) displayed correlation with reactor operation (1994-1998) and the partial dismantling of reactor systems (2007-2009). In 1998, the gross beta activity was smaller because SNR operation stopped in June.



Fig. 5. Average annual beta activity of water in the sewage and drainage of SNR. 
In December 2014, a high level of water pollution with tritium was detected in the control wells X1, and X2 (see Fig. 1): $4.96 \cdot 10^{3}$, and $2.15 \cdot 10^{3} \mathrm{~Bq} / 1$, respectively. The supposed cause was leakage from special sewage underground basin No.1 due to metal corrosion. Special sewage basins No.1 and No.2 are welded stainless steel tanks (diameter $-624 \mathrm{~cm}$; height $-230 \mathrm{~cm}$; metal thickness $-4 \mathrm{~mm}$ ) enclosed within concrete housings. Basins were built in 1960.

In order to liquidate the possible environmental pollution source and to eliminate possibility of future incidents, the deactivation and repair works plan was elaborated. This plan included regular dosimetry and water radioactivity control measurements and was approved by the National Radiation Safety Authority.

$101.2 \mathrm{~m}^{3}$ of contaminated water from sewage basins No.1, and No.2 were pumped out and filled into double layer containers (a 100 litre plastic barrel within a 200 litre metal barrel). Maximal measured dose rate on the outer surface of water containers was $0.9-1.0 \mu \mathrm{Sv} / \mathrm{h}$ due to the total Cs-137 activity of water in the container. These containers were stored: part in the temporary storage building, and part in the former reactor hall.

The radioactive sludge mixed with the ion exchange resin covering bottom of basin No.1 was gathered, packed in 14 metal barrels (2800 litres) and stored within A-172 type containers in the reactor hall. Since dose rate on some filled barrels was 25-30 $\mu \mathrm{Sv} / \mathrm{h}$, three barrels with sludge and scrap metal parts were cemented within A-172 type containers.

When all contaminated water and sludge were removed, both sewage basins were washed with pressurized water streams. Resulting radioactive water $(\sim 150$ liters) was pumped into the above-mentioned double layer containers and stored.

After the decontamination, the ambient gamma dose rate in basin No.1 was $1.5-3.0 \mu \mathrm{Sv} / \mathrm{h}$, and in basin No. $2-0.3-0.55 \mu \mathrm{Sv} / \mathrm{h}$.

Then, the seams of metal tanks in sewage basins No. 1, and No. 2 were checked and all detected cracks were welded.

Radioactivity control measurements were carried out during all stages of the emergency works as well as after completion of the task. Table 1 presents Cs-137, and $\mathrm{H}-3$ activity levels in both basins at main stages of the work. Registered activity of Co-60, natural radionuclides K-40, and U-238 was negligible, except in sludge at the bottom of basin No.1 where Co-60 massic activity reached $4330 \mathrm{~Bq} / \mathrm{kg}$.

Table 2 presents maximal Cs-137 and H-3 activities detected in the water of control wells of the SNR territory. Maximal activities were found in wells X1 and $\mathrm{X} 2$, which were closest to the basins. Figure 6 presents variations of tritium activity in control wells X1 and X2 during the incident and emergency works. The maximal Cs-137 massic activity $12.9 \mathrm{~Bq} / \mathrm{kg}$ was detected in the well X2 in the middle of March, 2015 when basins were washed.

Radionuclide content in other control wells of the SNR territory (see Fig. 7) was much lower: the maximal activity level $\sim 600 \mathrm{~Bq} / 1$ was observed in the well $5 \mathrm{~V}$. In some control wells, presence of natural radionuclides K-40 and U-238 in water was detected as well. It could be explained by washing out of clay layer. 
The Radioactivity Control Data of Sewage Basins During the Incident

\begin{tabular}{|c|c|c|c|c|c|}
\hline \multirow[t]{2}{*}{ Date } & \multicolumn{2}{|c|}{ Basin No.1 } & \multicolumn{2}{|c|}{ Basin No.2 } & \multirow[t]{2}{*}{ Comment } \\
\hline & $\begin{array}{l}\text { Cs-137 } \\
\mathrm{Bq} / \mathrm{kg}\end{array}$ & $\begin{array}{l}\mathrm{H}-3 \\
\mathrm{~Bq} / 1\end{array}$ & $\begin{array}{l}\text { Cs-137 } \\
\mathrm{Bq} / \mathrm{kg}\end{array}$ & $\begin{array}{l}\mathrm{H}-3 \\
\mathrm{~Bq} / \mathrm{l}\end{array}$ & \\
\hline 01.12 .2014 & $477 \pm 4 \%$ & $3.23 \cdot 10^{5} \pm 8 \%$ & $513 \pm 4 \%$ & $1.59 \cdot 10^{5} \pm 8 \%$ & $\begin{array}{l}\text { Water before } \\
\text { the incident }\end{array}$ \\
\hline 06.02 .2015 & & & $46 \pm 4 \%$ & $1.3 \cdot 10^{3} \pm 8 \%$ & $\begin{array}{c}\text { Water re- } \\
\text { moved from } \\
\text { basin No.2 }\end{array}$ \\
\hline 10.03 .2015 & $471 \pm 4 \%$ & $2.44 \cdot 10^{5} \pm 8 \%$ & & & $\begin{array}{c}\text { Water re- } \\
\text { moved from } \\
\text { basin No.1 }\end{array}$ \\
\hline 10.03 .2015 & $3.8 \cdot 10^{5} \pm 4 \%$ & - & - & - & Sludge \\
\hline 14.05 .2015 & $5.2 \pm 5 \%$ & - & $8 \pm 4 \%$ & - & $\begin{array}{c}\text { Control } \\
\text { measure- } \\
\text { ments }\end{array}$ \\
\hline
\end{tabular}

\section{Maximal Cs-137 and H-3 Activity Levels Detected in the Water of}

\section{Control Wells of the SNR Territory During the Incident}

\begin{tabular}{|l|c|c|}
\hline Well No. & $\begin{array}{c}\text { Cs-137 } \\
\text { Bq/kg }\end{array}$ & $\begin{array}{c}\text { H-3 } \\
\text { Bq/1 }\end{array}$ \\
\hline X1 & $2.8 \pm 5 \%$ & $3.88 \cdot 10^{4} \pm 8 \%$ \\
\hline X2 & $12.9 \pm 4 \%$ & $9.53 \cdot 10^{4} \pm 8 \%$ \\
\hline 5V & $1.7 \pm 5 \%$ & $581 \pm 9 \%$ \\
\hline 9V & $3.6 \pm 5 \%$ & $69 \pm 21 \%$ \\
\hline 10V & $1.6 \pm 5 \%$ & $193 \pm 12 \%$ \\
\hline 7A & $<0.5$ & $7 \pm 35 \%$ \\
\hline 1B & $1.2 \pm 6 \%$ & $71 \pm 21 \%$ \\
\hline 2A & $9 \pm 4 \%$ & $7 \pm 35 \%$ \\
\hline 2B & $<0.5$ & $<4$ \\
\hline 4A & $<0.5$ & $<4$ \\
\hline 4B & & \\
\hline
\end{tabular}

Measurements carried out after the incident showed that tritium content in wells outside the reactor fence was below limits allowed for drinking water. 




Fig. 6. Tritium activity concentration of water in control wells $\mathrm{X} 1$ and $\mathrm{X} 2$ during the incident.

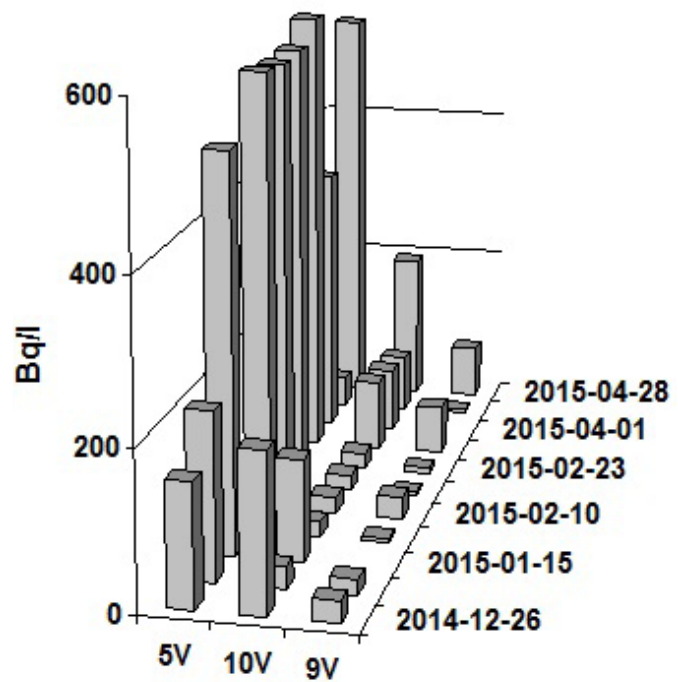

Fig. 7. Tritium activity concentration of water in other control wells close to the basins.

\section{CONCLUSIONS}

The obtained results presented dynamics of artificial radionuclide concentration in soils and ground waters in the vicinity of SNR depending on years and location.

1. The results of Cs-137 monitoring in soils showed that the massic activity varied in different places of the SNR territory. However, it did not exceed the average global Cs-137 fallout level value in the Latvian territory $(\sim 140 \mathrm{~Bq} / \mathrm{kg})$. 
2. The results of tritium, activity measurements show variation within a wide range (5-8000 Bq/1) for particular years. Seasonal changes of activity were established as well. The activity concentration of tritium in the wells outside the SNR territory was below the level permitted for drinking water in Latvia (100 Bq/1).

3. The determined gross beta activity level in the ground waters of the SNR territory was below $0.35 \mathrm{~Bq} / 1$, which was within limits permitted by regulations.

4. The performed monitoring allowed timely establishing the emergency situation related to the water leakage from the storage basin and ensuring the elimination of the possible large scale environmental pollution.

5. The monitoring showed that the amount of radionuclides produced by SNR had little impact on the total radionuclide content in the Latvian environment.

\section{REFERENCES}

1. Turner, J.E. (2007). Atoms, Radiation, and Radiation Protection. Weinheim: WILEY$\mathrm{VCH}$ Verlag $\mathrm{GmbH} \& \mathrm{Co}$. KGaA.

2. Berzins, J., Riekstina, D., Veveris, O., and Malnacs, J. (2009). Radiation control of some contaminated territory of Latvia. In Leben mit Stralung - von den Grundlagen zur Praxis. 6. Gemeinsame Tagung der Österreichischen Verbundes für Strahlenschutz ÖVS und der Deutsch/Schweizerischen Fachverbandes für Strahlenschutz FS mit Workshop der Österreichishen Gessellschaft für Medizinishe Physik ÖGMP. 41. Jahrestagung der FS. 21-25 September 2009, Alpbach, Tirol (pp. 182-187). TÜV Media GmbH, TÜV Rheinland Group, Köln.

3. Riekstina, D., and Veveris, O. (2010). Tritium concentration in drinking and ground water in Latvia. In International Conference on Advances in Liquid Scintillation Spectrometry. 6-10 September 2010, Paris, France (pp. 95-98) Joe Christensen, Inc., Lincoln, Nebraska, USA.

4. Veveris, O., Riekstina, D., Taure, I., and Skujina, A. (2003). Forest ecosystem as accumulator of radionuclides. Ecology 2, 53-55.

5. Rissanen, K., Ylipieti, J., Salminen, R., That, K., Giliucis, A., and Gregorauskiene, V. (2005). Cs-137 concentrations in the uppermost humus layer in the Baltic countries in 2003. INIS 36(47), Ref.No. 36109090. IAEA.

6. Latvian Cabinet of Ministers. (2002). Regulation of Protection against Ionizing Radiation. Regulations No.149, adopted 09.04.2002 with amendments No.629 of 04.11.2003. Riga.

7. European Commission. (1998). Directive 98/83/EC of 3 November 1998 on the Quality of Water Intended for Human Consumption. Luxembourg.

8. Latvian State Standard. (2008). LVS ISO 10703:2008 Water Quality-Determination of the Activity Concentration of Radionuclides - Method by High Resolution Gamma-Ray Spectrometry. Riga

9. Latvian State Standard. (2000). LVS ISO 257:2000 Building Material Quality - Determination of Radionuclides and Specific Activity of Radionuclides in Building Materials by Gamma Spectrometry. Riga. 
10. Canberra Industries. (1997). GENIE-2000. Basic Spectroscopy (Standalone) VI.2A Copyright.

11. Latvian State Standard. (2011). LVS ISO 9698:2011 Water Quality - Determination of Tritium Activity Concentration - Liquid Scintillation Counting Method. Riga.

12. Latvian State Standard. (2009). LVS ISO 10704:2009 Water Quality - Measurement of Gross Alpha and Gross Beta Activity in Non-saline Water. The Source Deposit Method. Riga.

13. International Organization for Standardization. (2008). ISO/IEC 17025:2005 General Requirements for the Competence of Testing and Calibration Laboratories.

14. Stauton, S., and Raunband, M. (1997). Adsorption of Cs-137 on montmorillonite and illite: Effect of charge compensating cation, ionic strength, concentration of Cs, K and fulfic acid. Clay and Clay Minerals 45(2), 251-260.

15. Riekstina, D., Veveris, O., and Zalitis, P. (1997). Forest litter as indicator of radioactive pollution. Baltic Forestry 3, 35-40.

\title{
APKĀRTĒJĀS VIDES MONITORINGA REZULTĀTI BIJUŠĀ SALASPILS KODOLREAKTORA TERITORIJĀ
}

\author{
D. Riekstiņa, J. Bērziņš, T. Krasta, G. Ķizāne, J. Rudzītis
}

\section{Kopsavilkums}

Darbs prezentē ilgākā laika periodā veiktā vides monitoringa rezultātus bijušā Salaspils pētnieciskā reaktora teritorijā. Ir sniegti dati par Cs-137 koncentrāciju augsnē, kā arī tritija koncentrāciju gruntsūdeņos. Tāpat sniegti dati par summāro beta aktivitāti gruntsūdeṇos speciālās un lietus kanalizācijas ūdeņos. İpaša uzmanība pievērsta radionuklidu koncentrācijas mērījumiem 2014. gada decembrī notikušās radioaktīvo ūdeņu noplūdes laikā, avārijas situācijas likvidācijas laikā, kā arī stāvokḷa novērtēšanai pēc incidenta.

17.12.2015. 